between 27 and 29 weeks, and in two between 16 and 20 weeks.

\section{Results}

The correlation coefficient for the ultrasound BPD and LMP estimations of gestational age was $+0 \cdot 8837, P<0 \cdot 0005$. The correlation coefficient for the Dubowitz scoring system and LMP estimations of gestational age was $+0.4128, \mathrm{P}<0.05$ (Table).

\section{Discussion}

When the gestational age estimated by these two methods was compared with that estimated from the date of the LMP of mothers certain of their dates, the estimation using ultrasound data correlated much more closely with that derived from the LMP than did that using the method of Dubowitz et al. (1970). Thus when accurate LMP data are not available, the most reliable method of assessing the gestational age is by ultrasound BPD measurement early in pregnancy. The superiority of the ultrasound method is particularly relevant in the case of sick neonates; these should be handled as little as possible and will therefore be assessed on external criteria only, although less accurate than the method of Dubowitz et al. (1970) which comprises neurological as well as external physical criteria.

I thank Dr B. King for information from the ultrasound department, Hilary Noakes who made the BPD measurements, Dr El Bishti for help with the statistics, and Professor R. J. Robinson for advice and encouragement.

\section{References}

Campbell, S., and Newman, G. B. (1971). Growth of the fetal biparietal diameter during normal pregnancy. Journal of Obstetrics and Gynaecology of the British Commonwealth, 78, 513-519.

Dubowitz, L. M., Dubowitz, V., and Goldberg, C. (1970). Clinical assessment of gestational age in the newborn infant. Journal of Pediatrics, 77, 1-10.

Lunt, R. M., and Chard, T. (1974). Reproducibility of measurement of foetal biparietal diameter by ultrasonic cephalometry. Journal of Obstetrics and Gynaecology of the British Commonwealth, 81, 682-685.

Parkin, J. M., Hey, E. N., and Clowes, J. S. (1976). Rapid assessment of gestational age at birth. Archives of Disease in Childhood, 51, 259-263.

Correspondence to Miss Deborah Mitchell, Boland House, Guy's Hospital Medical School, St Thomas Street, London SE1 9RT.

\title{
Breast milk and breast feeding in very low birthweight infants
}

\author{
J. L. PEARCE AND L. F. BUCHANAN
}

Department of Paediatrics, Taranaki Base Hospital, New Plymouth, New Zealand

SUMMARY The feeding of 17 babies weighing $<1500 \mathrm{~g}$ was examined retrospectively. 12 babies started breast feeding at a mean weight of $1324 \mathrm{~g}$ and 10 of them were fully breast fed by a mean weight of $1600 \mathrm{~g}$. Their weight gains were comparable with bottle-fed babies receiving expressed breast milk. Practical aspects of breast feeding were considered to be: a knowledgeable maternal and nursing attitude, close mother and baby contact, early expression of breast milk, and early suckling. The increased incidence of breast feeding by mothers of both low birthweight and term babies ensures regular supplies of fresh breast milk. Therefore, sterilication or storage of breast milk here is unnecessary.

Interest in feeding low birthweight infants has been revived by numerous scientific analyses of the properties of breast milk (British Medical Journal,
1978). Many papers are preoccupied with differences between treated and raw breast milk, and with the storage of milk in banks (Ford et al., 1977; Evans et al., 1978; Williamson et al., 1978). While tube feeding will inevitably be required in the management of very low birthweight babies, there is a danger that the ability of babies to suckle at the breast will be ignored and there are few studies on this aspect. Very low birthweight babies are usually the most difficult ones to feed. We therefore report on the management of the last 17 consecutive babies born in this unit weighing $<1500 \mathrm{~g}$, with particular reference to breast feeding:

\section{Materials and methods}

The babies weighed between 750 and $1500 \mathrm{~g}$ (mean $1272 \pm 190$ SD) and 13 were appropriate for gestational age. All babies were managed in a neonatal unit. Major complications were encountered by 2 
babies who required ventilation, and 3 who required continuous positive airways pressure for respiratory distress syndrome or apnoea. 14 babies received IV fluids for a mean period of $3 \frac{1}{2}$ days. No other parenteral alimentation was given. The babies received 800 units vitamin D and $60 \mathrm{mg}$ vitamin C daily after feeds were begun.

All babies were fed by a standard regimen of intermittent gastric gavage if their condition permitted. Breast or bottle feeding was started when sucking movements were noted. Gavage feeding was continued according to the success of breast feeding and satisfactory weight gain.

All low birthweight babies in this unit are fed expressed breast milk. Milk is manually expressed or allowed to ejaculate into sterile bowls and refrigerated. It is not boiled or frozen and is discarded after 24 hours. Milk was donated by mothers of babies in the neonatal unit and in the postnatal maternity ward. Mothers were asked about breast feeding within a few hours of birth and encouraged to express milk, particularly colostrum, to feed their babies. They were encouraged to assist with gavage feeding. Babies who were breast fed did not receive bottle feeds.

Weight gains of all babies were plotted on standard growth grids (Dancis et al., 1948) and growth of head and length was recorded.

\section{Results}

12 babies started breast feeding at a mean weight of $1324 \pm 99 \mathrm{~g} \mathrm{SD}$, and mean age of 11 days. The 10 babies who were successful were fully breast fed by a mean weight of $1600 \pm 139 \mathrm{~g}$, and a mean age of 27 days. All the breast milk for these babies was provided by their mothers from the 2 nd or 3rd day postpartum. Of the 2 mothers who failed, one had waited for $\mathbf{3 0}$ days before starting breast feeds and was unable to keep lactating, the other fed for 5 weeks and gave up for 'convenience' just before discharge. Complete breast feeding usually coincided with stable temperature control and the babies were discharged at a mean weight of $1677 \pm 104 \mathrm{~g}$. Mean weekly weight gains for the 11 babies who were breast fed in the neonatal period are given in the Table. A transient slowing of weight gain after withdrawal of supplementary milk was common.

Table Weekly weight gains (mean $\pm 1 S D$ ) of breastand bottle-fed babies

\begin{tabular}{lllll}
\hline & \multicolumn{4}{l}{ Weeks } \\
\cline { 2 - 5 } & 1 & 2 & 3 & 4 \\
\hline Breast fed (g) & $-82 \pm 79$ & $141 \pm 40$ & $148 \pm 41$ & $134 \pm 73$ \\
Bottle fed (g) & $-89 \pm 59$ & $133 \pm 35$ & $134 \pm 81$ & $159 \pm 50$ \\
\hline
\end{tabular}

The amount of supplementary milk given to these babies was too variable to tabulate. The parents of these babies were white; one was unmarried.

The weight gains of the 6 babies given untreated expressed breast milk by bottle were comparable with those breast fed (Table). Of the mothers of these babics, 5 were of mixed blood (Maori, Indian, and European) and 5 were unmarried.

\section{Discussion}

This study shows that very low birthweight babies can be breast fed early. The mean weight and small standard deviation at which babies started breast feeding suggests that they are mature enough to suckle when they are about $1300 \mathrm{~g}$. There were no complications attributed to early breast feeding. Successful breast feeding, particularly of very low birthweight babies, is attributed to many factors: unrestricted visiting of mother and family to the neonatal unit, an optimistic and knowledgeable attitude of the nursing staff to breast feeding, and babies to be breast fed being virtually never bottle fed. The problem of maintaining maternal milk secretion is paramount. Manual or hand pump expression of milk was used and we have no experience with mechanical breast pumps. On occasions, mothers breast fed other babies to stimulate milk secretion. Breast feeding a very low birthweight baby demands tremendous maternal commitment and co-operation, often for long periods. It is therefore essential to provide facilities for mothers to stay beside the neonatal unit without the usual hospital restrictions.

As would be expected, the main factor against breast feeding was maternal disinclination, strongly associated with sociological and racial factors.

Untreated expressed breast milk and breast feeding produced adequate weight gains in this small group of very low birthweight babies as judged from the weight grids used. Weight grids that are derived from cows' milk-fed low birthweight babies can, at best, only provide reference points. Optimum weight gains are unknown. The advantages of breast milk over cows' milk substitutes have been reviewed elsewhere (Addy, 1976; Jelliffe and Jelliffe, 1977). The use of untreated breast milk appears safe (Hack et al., 1975) and probably preserves the antibacterial properties which are reduced by most methods of sterilisation (Ford et al., 1977; Evans et al., 1978).

The availability of milk has increased in recent years with the trend towards breast feeding. Therefore, in this region, storage of milk in banks is unnecessary. The present emphasis on milk storage and sterilisation is misplaced. The emphasis should 
be on educating and encouraging mothers to breast feed their own babies. A high rate of breast feeding in neonatal units and postnatal wards will ensure a ready supply of fresh expressed breast milk.

\section{References}

Addy, D. P. (1976). Infant feeding: a current view. British Medical Journal, 1, 1268-1271.

British Medical Journal (1978). Editorial: The special care of human milk. British Medical Journal, 2, 781-782.

Dancis, J., O'Connell, J. R., and Emmett Holt, L., Jr (1948). A grid for recording the weight of premature infants. Journal of Pediatrics, 33, 570-572.

Evans, T. J., Ryley, H. C., Neale, L. M., Dodge, J. A., and Lewarne, V. M. (1978). Effect of storage and heat on antimicrobial proteins in human milk. Archives of Disease in Childhood, 53, 239-241.
Ford, J. E., Marshall, V. M. E., and Reiter, B. (1977). Influence of the heat treatment of human milk on some of its protective constituents. Journal of Pediatrics, 90, 29-35.

Hack, M., Boxerbaum, B., and Fanaroff, A. (1975). Fresh human milk: bacterial flora in urban US mothers (abstract). Pediatric Research, 9, 304.

Jelliffe, D. B., and Jelliffe, E. F. P. (1977). Breast is best: modern meanings. New England Journal of Medicine, 297, 912-915.

Williamson, S., Hewitt, J. H., Finucane, E., and Gamsu, H. R. (1978). Organisation of bank of raw and pasteurised human milk for neonatal intensive care. British Medical Journal, 1, 393-396.

Correspondence to Dr J. L. Pearce, 99 Springfield Road, Sheffield 7, Yorkshire.

\title{
Is it necessary to warm infants' feeds?
}

\author{
C. COSTAlOS, I. ROSS, A. G. M. CAMPBELL, AND M. SOFI \\ Department of Child Health and Department of Chemical Pathology, University of Aberdeen, Scotland
}

SUMMARY The effect of temperature on gastric emptying after milk feeds was studied in $\mathbf{3 1}$ newborn infants. Test meals were a commercially prepared modified cows' milk (a) at body temperature and (b) at room temperature. Our results suggest that temperature has no effect on gastric emptying.

Before feeding a baby it is customary to warm the milk to approximately body temperature. This time-consuming procedure is presumably designed to mimic breast feeding as closely as possible. Even today when prepacked feeds are widely used, most mothers prefer to warm their babies' feeds, often using bottle-warmers which may be a fire hazard and a source of infection. Because food temperature has been shown to influence the rate of gastric emptying in adults (Ritschel and Erni, 1977) we decided to study the effect of feed temperature on gastric emptying in the newborn period.

\section{Methods and infants}

31 infants born in Aberdeen Maternity Hospital were studied. Their characteristics are shown in the Table. All the babies were being fed routinely via indwelling polyvinyl nasogastric tubes every 4 hours. The method of serial test meals used for adults (Hunt, 1951) had been modified for studying gastric emptying in the newborn (Husband and Husband, 1969). Initially the stomach was washed out with
Table Gastric emptying in 31 newborn infants after test meals of 'warm' and 'cool' milk

\begin{tabular}{|c|c|c|c|c|}
\hline \multirow[t]{2}{*}{ Case } & \multirow[t]{2}{*}{$\begin{array}{l}\text { Gestational age } \\
\text { (weeks) }\end{array}$} & \multirow[t]{2}{*}{ Day of life started } & \multicolumn{2}{|c|}{$\begin{array}{l}\text { Test meal }(\%) \\
\text { recovered from } \\
\text { stomach after } 30 \\
\text { min }\end{array}$} \\
\hline & & & Warm & Cold \\
\hline 1 & 33 & 2 & $52 \cdot 76$ & $38 \cdot 60$ \\
\hline 2 & 36 & 5 & $64 \cdot 00$ & $70 \cdot 50$ \\
\hline 3 & 35 & 17 & $63 \cdot 12$ & $88 \cdot 70$ \\
\hline 4 & 38 & 3 & 63.45 & $56 \cdot 10$ \\
\hline 5 & $38 \cdot 5$ & 3 & $69 \cdot 50$ & $71 \cdot 66$ \\
\hline 6 & 35 & 9 & 69.80 & $37 \cdot 20$ \\
\hline 7 & 36 & 11 & 64.02 & 94.45 \\
\hline 8 & 40 & 10 & $75 \cdot 00$ & $63 \cdot 52$ \\
\hline 9 & 31 & 23 & $65 \cdot 50$ & $73 \cdot 80$ \\
\hline 10 & 38 & 4 & 52.86 & $69 \cdot 20$ \\
\hline 11 & 37 & 5 & 56.03 & $60 \cdot 20$ \\
\hline 12 & 36 & 3 & $46 \cdot 63$ & 55.00 \\
\hline 13 & 38 & 3 & $70 \cdot 33$ & $75 \cdot 23$ \\
\hline 14 & 36 & 4 & $72 \cdot 70$ & $56 \cdot 33$ \\
\hline 15 & 36 & 4 & $70 \cdot 83$ & $66 \cdot 93$ \\
\hline 16 & 35 & 4 & 52.06 & 35.83 \\
\hline 17 & 35 & 5 & $41 \cdot 00$ & $65 \cdot 26$ \\
\hline 18 & 33 & 8 & $61 \cdot 23$ & 79.90 \\
\hline 19 & 35 & 4 & $53 \cdot 35$ & 65.00 \\
\hline 20 & 32 & 8 & $41 \cdot 20$ & $53 \cdot 33$ \\
\hline 21 & 36 & 2 & 78.06 & 70.00 \\
\hline 22 & $32 \cdot 5$ & 30 & $60 \cdot 26$ & $78 \cdot 76$ \\
\hline 23 & 36 & 16 & $58 \cdot 53$ & $65 \cdot 00$ \\
\hline 24 & 32 & 5 & $83 \cdot 80$ & $53 \cdot 73$ \\
\hline 25 & 36 & 4 & 60.00 & $51 \cdot 33$ \\
\hline 26 & $35 \cdot 5$ & 6 & $63 \cdot 33$ & 64.43 \\
\hline 27 & 35 & 19 & $51 \cdot 60$ & $53 \cdot 33$ \\
\hline 28 & 36.5 & 4 & $61 \cdot 30$ & 66.40 \\
\hline 29 & 34 & 7 & $71 \cdot 20$ & $58 \cdot 05$ \\
\hline 30 & 32 & 41 & $60 \cdot 33$ & $52 \cdot 76$ \\
\hline 31 & 36 & 2 & 40.00 & 57.40 \\
\hline & & Mean & $61 \cdot 72$ & $62 \cdot 10$ \\
\hline & & SEM & 1.86 & $2 \cdot 38$ \\
\hline
\end{tabular}

